\title{
Psychological Profiling of Criminals in Violent Crime Investigations in Nigerian Criminal Justice System
}

\author{
Kolawole Shittu Adebisi ${ }^{*}$ and Daramola Nurudeen Olanrewaju
}

\author{
General Studies Department, The Polytechnic, Ibadan, Oyo State, Nigeria
}

\begin{abstract}
The Nigerian criminal justice system is not entirely ignorant or unaware of the use and the merits of the application of criminal profiling as a tool in crime investigation. The technique was introduced to help law enforcement agencies solve serious crimes such as serial rape or murder and to a lesser extent arson and property crime. At the heart of profiling lies the belief that by combining psychological principles with crime scene analysis, it is possible to identify the likely characteristics of a perpetrator. However, criminal profiling in Nigeria has not nearly reached the level of recognition, functionality, or institutionalization that it has attained in other jurisdictions. This study aims to examine the feasibility and the practicality of offender profiling in a criminal investigation of violent crimes with a particular focus on the Nigerian criminal justice system. It will also give an expository critique of the loopholes and impediments in the Nigerian criminal justice system and ways criminal profiling can fill up these holes. The research methods employed in this study include a combination of both primary and secondary sources. The work highlighted the effectiveness of this field and thus concluded that criminal investigative analysis should be effectively immersed into the justice system and should also receive as much recognition as it has in other jurisdictions especially in the United States and in major parts of Europe.
\end{abstract}

Keywords: Criminal Profiling, Crime Investigation, Violent Crime, Criminal Justice System.

\section{INTRODUCTION}

The term criminal profiling has, at times, come to be understood as meaning different things, and part of the confusion arises from the different nomenclature used often interchangeably, including offender profiling, criminal personality profiling, investigative profiling, and psychological profiling. Descriptions of criminal profiling have included "a collection of leads" (1) and a "biological sketch of behavioral patterns, trends, and tendencies" (2). More detailed descriptions of criminal profiling, however, include the following:

A forensic technique that seeks to provide investigative agencies with specific information will help focus attention on individuals with personality traits that parallel traits of other perpetrators who have committed similar offenses (Geberth, 1983 p. 236).

or

The process of identifying personality traits, behavioural tendencies, and demographic variables of an offender based on characteristics of the crime (Bartol \& Bartol, 1994 p. 167).

More recent descriptions of profiling have suggested the following:

*Address correspondence to this author at the General Studies Department, The Polytechnic, Ibadan, Oyo State, Nigeria; Tel: 08035629856

E-mail: adebisi.kolawole@polyibadan.edu.ng
Criminal profiling refers to the process of identifying personality traits, behavioural tendencies, geographic locations, and demographic or biological descriptions of an offender based on characteristics of the crime (Hickey, 2003 p. 186).

....an attempt to provide investigators with more information on a serial murderer who is yet to be identified (Egger, 2003 p. 193).

Irrespective of the particular descriptions used, at their most basic level, all effectively attempt to describe the same underlying concept. That is, criminal profiling represents a process whereby behaviours and/or actions exhibited in a crime are assessed and interpreted to form predictions concerning the characteristics of the probable perpetrator(s) of the crime. The composite predicted characteristics are often referred to as a criminal profile, the purpose of which is to assist investigators, typically police personnel, in the identification and thus apprehension of an unknown criminal or criminals. For simplicity, and in an attempt to minimize further confusion throughout the remainder of this paper, the term criminal profiling or simply profiling is adopted.

Having provided some exposition of what criminal profiling is, it is also important to identify and distinguish such profiling from other similarly described concepts. Criminal profiling and criminal profiles within the context of this work should not be confused with aggregated profiles that are also sometimes referred to 
as racial/ethnic profiles or racial profiling. Criminal profiling refers to the systematic analysis of an individual crime or related series of crimes to construct a profile that describes the various characteristics of the offender likely to have committed the crime(s) specifically under examination (Ezeanya, 2015). The use of criminal profiling commonly arises in the context of an on-going criminal investigation into a crime or crime series. Racial profiles, on the other hand, represent aggregated demographic templates of the typical type of individual who is believed to commit certain forms of crime (Tyler \& Wakslak, 2004).

The practice of criminal profiling is a very novel area and not commonly used by law enforcement agencies in Nigeria especially the Nigeria Police Force for the various investigations they conducted (Ezeanya, 2015). As against this, profiling is widely used in discovering crimes by law enforcement agencies in developed countries most importantly the Federal Investigations Bureau (FBI), the USA, and other agencies in the western countries. Criminal profiling needs to be enshrined into the Nigerian criminal justice system in a criminal investigation because of its enormous benefits which will be helpful and without mincing words, there is a need to improve crime prevention and detection in Nigeria criminal justice thus the need for this work.

\section{LITERATURE REVIEW}

\subsection{The Nigerian Criminal Justice System}

Criminal justice may be defined as a system or as a process. As a system, it is made up of three subsystems or components: the police, the courts, and corrections responsible for law enforcement. IwerimieJaja (2003) defined the criminal justice system as a process when the different components co-ordinate their independent functions by processing the criminal suspect from one stage to the other. The criminal justice process involves an arrest, booking, trial, and confinement. Once a crime is reported to the police investigation begins; witnesses are interviewed or interrogated. Sufficient information obtained leads to the arrest of a suspect who may be detained or placed in police custody, or even released on bail, where there seems to be no threat. Police discretion could be exercised at this stage, either to charge or discharge the suspect.

As a legal process, criminal justice includes the procedure of processing the person accused of committing a crime from arrest to the final disposal of the case. According to Clare and Kramer:
It is possible to view criminal justice as a consequence of the decision making stages. Through this system, offenders are either passed on to the next stage or diverted out of the system. This diversion may be due to several reasons such as lack of evidence or a desire to reduce the load on the system. Each subsequent stage of the process is dependent upon the previous stage for its elements; it is this dependence that best exemplifies the "system" nature of criminal justice (Clare and Kramer, 1977 p. 23).

The Nigerian criminal justice system encapsulates the police and their operations, the courts and the prisons, and other correctional or rehabilitative facilities. However, the focus in this work has been limited to the investigative stage of the system within which the police finds its primary relevance. Police are the most visible governmental agents through which the character of a government and political system may be assessed. This is so because the police are the guardian or vanguards of the status quo. The police are the biggest, most visible, and important sub-system of the criminal justice system. They provide the entry point into the criminal justice system through crime reports from the public or through its discovery (Ezeanya, 2015). The police organization is the main institution that makes it different among other components of the criminal justice system. The uniqueness of the police borders on the fact that the decision of the policeman on the street is as important as the existence of the criminal justice system. The policeman is the gatekeeper of the criminal justice system as he decides who goes into the system and his decision has wider implications for the other components. The policeman lubricates the system through the arrest of suspects, who are essentially the inputs into the criminal justice system (Onimajesin, 2010).

Force Criminal Investigation Departments (FCID) is the highest investigation arm of the Nigeria Police. The department is headed by a Deputy Inspector-General (DIG). Its primary roles include investigation and prosecution of serious and complex criminal cases within and outside the country. The department also coordinates crime investigations throughout the Nigeria Police Force. The NPF-CID is divided into sections, with most of them headed by Commissioners of Police. The sections are: 

(a) Administration
(b) Anti-Fraud Section
(c) The Central Criminal Registry (CCR)
(d) Defunct Special Anti-Robbery Squad (SARS)
(e) X-Squad
(f) General Investigation
(g) Special Fraud Unit (SFU)
(h) Legal Section
(i) Forensic Science Laboratory
(j) Interpol Liaison Homicide
(k) Anti-Human Trafficking Unit
(I) Special Branch CIB/SIB

(m) Force CID Kaduna Annex (The World Factbook, 2011).

\subsection{Current Standards in Criminal Investigation in Nigeria}

Someone was murdered today. Police were crawling over the neighborhood, collecting evidence, and taking statements. The case can be solved. Investigators will deliver evidence to the laboratory, profile the DNA gathered at the scene, and run the fingerprints through the Automated Fingerprint Identification System (AFIS). There should be a match. This could be a scene out of just about any of television's hit crime dramas. Today, forensic television is a staple of prime-time TV. But investigating a murder can be much more difficult when there is no AFIS, no DNA database, and no fancy equipment. This may sound like a blast from some time long past, but it's not. This is the situation in our country Nigeria.

In Nigeria, many crimes were not resolved to date because of a lack of adequate equipment and training. Police do rarely take fingerprints; there is no DNA laboratory, and there are only a few ballistics experts in the country (http://www.dailynebraska.com). With over 200 million people, Nigeria is Africa's most populous nation and also one of the world's largest democracies but even Nigerians admit the inadequacy of their criminal justice system. A criminal justice system where fingerprint technology, which is stated as one of the most reliable methods of solving crime, is moribund in the country, while there is a contract to purchase a \#2.3 billion bullet-proof helicopter for the police is the kind that operates in Nigeria (Ashley burns, 2009). Experts have attributed the absence of forensic evidence to many unresolved crimes that flood Nigeria's criminal justice system. The investigation, solving, and prevention of crimes have been inhibited in Nigeria as a result of inadequate and lack of regular training. The poor training that police officers go through lacks global competitiveness.

The Nigerian Police could not uncover most of the high-profile murders in the country because the forensic investigation is now the core of crime investigation which the force does not possess. The police need to be equipped with experts and equipment to be able to fight and solve violent crimes in the country (Alemika, 1993). At our peril, the force has ignored taking and storing the fingerprints of convicts which is a statutory requirement. The police authorities purchased an Automated Fingerprints Identification System (AFIS) some years ago. The equipment can compare known fingerprints stored in its memory with unknown ones; if there is a match, the system will highlight it. But since Nigeria Police has stopped taking fingerprints for quite some time, it is not known from where they are going to get the fingerprints that will be stored in the system (Database) for comparison.

There is no single fingerprint expert in the Nigerian police other than those with little or no science background and inadequate training that have been incharge for years. Fingerprint technology has advanced so much that it could be developed on the human skin, clothing, porous surfaces, ammunition, firearms, etc. Criminals such as kidnappers, armed robbers, and car snatchers do have their fingerprints on hijacked vehicles, abandoned weapons, etc. which are not lifted for identification and comparison purposes. It is very unfortunate and highly preventable when criminals escape detection due to the unprofessionalism in the Nigeria Police Force (Adeyemi, 2011).

The ballistic section of a forensic laboratory is not usually invited for assistance in the investigation of shooting cases whereas the government only has an interest in procuring equipment and training without laying emphasises on the caliber of officers who will use the equipment and be trained. The Nigerian police are faced with a dearth of modern equipment, skills, and capability to solve high-profile murder cases. There is only one forensic laboratory in the whole country and it is poorly equipped, and that finger-printing, a basic 
but highly important means of investigation is no longer in use in Nigeria. Eye-witness accounts and confessional statements are frequently used instead of modern scientific evidence. The country has only a few ballisticians in the country which accounts for why the police cannot detect gunshot-related crime and that there is no data-base for criminals in Nigeria (Uduma, 2009).

Inadequate forensic and scientific tools are major challenges to crime investigators today in Nigeria. The present state of scientific investigation facilities in the country makes a mockery of the justice system as Nigeria police have for a longtime faced institutional neglect. Many crimes are committed in the dark, in secret, out of sight, that it is almost impossible to obtain a statement from an eye witness, identifying the actual participants on which to base a successful arrest and prosecution. Due to this problem, not once have the police checked the hands or clothes of a suspect alleged to have used a firearm for powder burns, a routine but important procedure abroad.

It is on record that Nigeria has only one barely functioning forensic laboratory located in Lagos. Worse still, the laboratory suffers serious government neglect, resulting in a severe shortage of relevant chemicals and reagents and poorly motivated staff. Items such as knives, clubs, and other weapons suspected to have been used to perpetrate homicide are often kept for months thereby holding up the investigation and trial process, and even when they are returned, no useful findings would have been made.

Criminal cases where fingerprints were used during trial seem not to exist in Nigeria in recent times and it is hoped that judges will be more demanding of the police of their present unscientific levels of the investigation so that perhaps the authorities might be forced to upgrade capability. The Nigeria police authority has not considered it necessary to develop a database of all suspects arrested by their various commands despite the fall in the prices of basic computer components not to even mention a record of fingerprints (Uduma, 2009).

\subsection{Theoretical Framework}

The ideological school of thought that this work based its profiling of crimes is that of Investigative Psychology (IP). The founder of this approach is British Psychologist Professor David Canter (1989). As the term implies, IP involves many significant ideological nuances. Foremost among these is its conceptualization of profiling as part of an emerging scholarly discipline (Canter, 1994). That is, IP appears to be conceived as a discrete discipline of scientific endeavour concerned with the application of the discipline of psychology to the study of crimes and their investigation. Unlike the Central Intelligence Agency (CIA), which views profiling more in terms of a practiced technique, IP appears to adopt a much broader view in embracing a broad disciplinary-based understanding of criminal behaviour. As a consequence, the evaluation of criminal behaviours and the associated prediction of offender characteristics from those behaviours (aka criminal profiling) represent only one type of activity within the scholarly boundary of knowledge collectively argued to fall under the banner of IP. As a consequence, the ideology of IP appears to adopt a much broader conceptualization surrounding the scope of its application and thus extends beyond aberrant violent crimes and into more conventional forms of crime (Brewer and Williams, 2005; Salfati, 2000). This is another notable characteristic of IP distinct from other approaches that are mostly orientated toward more atypical intractable violent crimes.

The methodology underpinning the IP approach to profiling is predominantly characterized by a stylized procedure for the ideographic analysis of criminal behaviours and offender characteristics using the statistical tool of multidimensional scaling (MDS). In what appears to be the first publication characteristic of the IP approach, Canter and Heritage (1989) posit that other endeavours are flawed and argue that the effective profiling of crimes requires the differentiation of crime behaviours as distinct from the inference of motivations. The entanglement of these constructs is argued to be present in much of the previous literature such as that of the CIA (Canter and Heritage, 1989). Thus, over the years, researchers operating under the IP banner have produced a variety of studies focused on espousing thematic patterns in offense behaviours of various forms of crime (Canter and Fritzon, 1998; Salfati, 2000; Alison, 2005).

What is perhaps most important to appreciate in differentiating the ideological characteristics of IP is not only the exact methodological procedure concerning how the MDS statistic is used but how the results of the analyses are put to use. In the context of IP, the MDS statistic is typically used to undertake two separate sets of analyses (i.e., one of criminal behaviours and the other, offender characteristics). The results of these 
analyses form the basis for developing an understanding or theorems concerning patterns or aspects inherent to such criminal behaviours as well as discernable groups of descriptive characteristics for the offenders of those crimes. An example of the IP methodology and its characteristic use of MDS is an analysis of domestic homicides to generate a theorem that argues that the perpetration of such crimes can be differentiated based on either serving an "instrumental" or "expressive" purpose (Arrigo and Shipley, 2005). Alongside such conceptions will typically be another set of analyses concerned with patterns in offender characteristics that may relate to either of these behavioural themes. Consequently, constructing a criminal profile (in the traditional context) when tackled from the IP perspective involves an examination of the crime in question regarding a previously developed theorem concerning the relevant form of criminal behaviour to in turn espouse characteristics about any given offender (Brown, Shell \& Cole 2015).

\section{RESEARCH METHODOLOGY}

The research methodology entails the use of both primary and secondary data from a literature review of books, articles, journals, and primary data from legislations, cases, reports of committees, and possibly collect data from the Nigerian Police archive. A critical analysis of particularly the criminal justice practices and procedures and criminology textbooks were done.

\section{RESULT AND DISCUSSIONS}

\subsection{Strategies in Criminal Profiling}

Investigative profilers at the FBl's Behavioural Science Unit (now part of the National Centre for the Analysis of Violent Crime [NCAVC]) have been analyzing crime scenes and generating criminal profiles since the 1970s. The criminal profile generating process of the NCAVC is the commonest profile generating process and it has five main stages.

\subsubsection{The Profiling Inputs Stage}

The profiling inputs stage is the starting point of the criminal-profile-generating process (Palermo and Kocsis, 2005). Detailed case materials are important for accurate profiling. A complete outline and a description of the crime scene as at the time of the incident such as the weather condition, political, and social environment are required information needed in a homicide case (Turvey, 2005).
It is also necessary to have full background information of the victim in homicide profiles. The data should include domestic setting, employment, reputation, habits, fears, physical condition, personality, criminal history, family relationships, hobbies, and social conduct (Turvey, 2005). Forensic information about the crime is also vital to the profiling process, including an autopsy report with toxicology/serology results, autopsy photographs, and photographs of cleansed wounds. The report should also contain the medical examiner's findings and impressions regarding estimated time and cause of death, type of weapon, and suspected sequence of delivery of wounds (Palermo, 2002).

In addition to autopsy photographs, aerial photographs (if available and appropriate) and $8 * 10$ colour pictures of the crime scene are needed (Palermo, 2002). Also needed are crime scene sketches showing distances, directions, and scale, as well as maps of the area (which may cross law enforcement jurisdiction boundaries). The profiler studies all this background and evidence information, as well as all initial police reports (Palermo, 2002). The level of risk of the victim, the degree of control exhibited by the offender, the offender's emotional state, and his criminal sophistication are the critical elements that data and photographs can reveal. Case materials will not include information dealing with possible suspects. Such information may subconsciously prejudice the profiler and cause him or her to prepare a profile matching the suspect (O'Toole, 1999).

\subsubsection{Decision Process Models Stage}

The decision process commences with the organizing and arranging of the inputs into meaningful patterns. Seven key decision points, or models, differentiate and organize the information from stage 1 and form an underlying decisional structure for profiling.

\subsubsection{Homicidal Type and Style}

Homicides are classified into type and style. A single homicide involves one victim, one homicidal event; double homicide is two victims, one event, and in one location; a triple homicide has three victims in one location during one event. Any number above three victims is classified as a mass murder; that is, four or more victims in one location, and within one event (O'Toole, 1999). 
There are two types of mass murder which are classic and family. A classic mass murder involves one person operating in one location at one period of time. That period could be minutes or hours and might even be days. The classic mass murderer is a mentally disordered individual whose problems have gotten to the extent that he acts against groups of people unrelated to these problems. He unleashes his hostility through shootings or stabbings (O'Toole, 1999). An example of a classic mass murderer was Charlse Whitman, the man who armed himself with boxes of ammunition, weapons, ropes, a radio, and food; barricaded himself on a tower in Austin, Texas; and opened fire for 90 minutes, killing 16 people and wounding over 30 others. He was stopped only when he was killed during an assault on the tower (Holmes and Holmes, 1996).

The second type of mass murder is family mass murder. A situation where three or more members of a family are killed and the perpetrator decided to kill himself is classified as a mass murder/ suicide. Without the suicide and with four or more victims, the murder is called a family killing (Holmes and Holmes, 1996). Examples include John List, an insurance salesman who killed his entire family on November 9, 1972, in Westfield, New Jersey, USA. The bodies of List's wife and three children (ages 16, 15, and 13) were discovered in their front room lying side by side on top of sleeping bags as if in a mortuary. Their faces were covered and their arms were folded across their bodies. Each had been shot once behind the left ear, except one son who had been shot multiple times. A further search of the residence discovered the body of List's mother in a third-floor closet. She had also been shot once behind the left ear. List disappeared after the crime and his car was found at an airport parking lot (Holmes and Holmes, 1996).

Two additional types of multiple murders are spree and serial. A spree murder does not contain any emotional cooling-off period between murders and also involves murdering at two or more locations. The killings are all the result of a single event, which can be of short or long duration (Douglas, 1986). Serial murderers are involved in three or more separate events with an emotional cooling-off period between homicides. This type of killer usually premeditates his crimes, often fantasizing and planning the murder in every aspect with the possible exception of the specific victim. Then, when the time is right for him and he is cooled off from his last homicide, he selects his next victim and proceeds with his plan. The cool-off period can be days, weeks, or months; and is the main element that separates the serial killer from other multiple killers (Douglas, 1986).

However, there are other differences between the murderers. The classic mass murder and the spree murder are not concerned with who their victims are; they will kill anyone who comes in contact with them. In contrast, a serial murderer usually selects a type of victim. He thinks he will never be caught, and sometimes he is right. A serial murderer controls the events, whereas a spree murderer, who oftentimes has been identified and is being closely pursued by law enforcement, may barely control what will happen next. The serial killer is planning, picking, and choosing, and sometimes stopping the act of murder (Douglas, 1981).

\subsubsection{Primary Intent of the Murder}

In some cases, murder may be an ancillary action and not itself the primary intent of the offender. The killer's primary intent could be criminal enterprise; emotional, selfish, or cause-specific, or; sexual. The killer may be acting on his own or as part of a group (Anthony and Norman, 1990). When the primary intent is a criminal enterprise, the killer may be involved in the business of crime as his livelihood. Sometimes murder becomes part of this business even though there is no personal malice toward the victim. The primary motive is money (Douglas, 1986).

When the primary intent involves emotional, selfish, or cause-specific reasons, the murderer may kill in selfdefence or compassion (mercy killings where life support systems are disconnected) (Douglas, 1986). Family disputes or violence may lie behind infanticide, matricide, patricide, and spouse and sibling killings. Paranoid reactions may also result in murder as in the previously described Whitman case (Douglas, 1986). The mentally disordered murderer may commit a symbolic crime or have a psychotic outburst. Assassinations also fall into the emotional intent category. The murderer may also have sexual motives for killing. Individuals may kill as a result of or engage in sexual activity, dismemberment, mutilation, evisceration, or other activities that have sexual meaning only for the offender (Douglas, 1986).

\subsubsection{Victim Risk}

As earlier discussed in victimology, the type of victim can show the character of the offender and his modus operandi (MO). Risk is determined using such factors as age, occupation, lifestyle, physical stature, 
resistance ability, and location of the victim, and is classified as high, moderate, or low (Petherick, 2003). Killers seek high-risk victims at locations where people may be vulnerable, such as bus depots or isolated areas. Low-risk types include those whose occupations and daily lifestyles do not lead them to be targeted as victims. The information on victim risk helps to generate an image of the type of perpetrator being sought (Petherick, 2003).

\subsubsection{Offender Risk}

Data on victim risk integrates with information on offender risk, or the risk the offender was taken to commit the crime. For example, abducting a victim at noon from a busy street is a high risk. Thus, a low-risk victim snatched under high-risk circumstances generates ideas about the offender, such as personal tresses he is operating under, his beliefs that he will not be apprehended, or the excitement he needs in the commission of the crime, or his emotional maturity (Douglas, 1986).

\subsubsection{Time Factors}

Several time factors need to be considered in generating a criminal profile. These factors include the length of time required: to kill the victim, to commit additional acts with the body, and, to dispose of the body. The time of day or night that the crime was committed is also important, as it may provide information on the lifestyle and occupation of the suspect (and also relates to the offender risk factor) (Douglas, 1986).

\subsubsection{Location Factors}

Information about location- where the victim was first approached, where the crime occurred, and if the crime and death scenes differ, provide yet additional data about the offender. For example, such information provides details about whether the murderer used a vehicle to transport the victim from the death scene or if the victim died at her point of abduction.

\subsubsection{Crime Assessment Stages}

The crime assessment stage in generating a criminal profile involves the reconstruction of the sequence of events and the behaviour of both the offender and the victim. Based on the various decisions of the previous stage, this reconstruction of how things happened, how people behaved, and how they planned and organized the encounter provides information about specific characteristics to be generated for the criminal profile.

\subsubsection{Criminal Profile Stage}

This stage deals with the type of person who committed the crime and that individual's behavioural organization about the crime. Once this description is generated, the strategy of investigation can be formulated, as this strategy requires a basic understanding of how an individual will respond to a variety of investigative efforts. Included in the criminal profile are background information (demographics), physical characteristics, habits, beliefs and values, preoffence behaviour leading to the crime, and postoffence behaviour. It may also include investigative recommendations for interrogating or interviewing, identifying, and apprehending the offender (Chu, Daffern, Thomas, Ang \& Long 2014).

\subsubsection{Investigative Stage}

Once the congruence of the criminal profile is determined, a written report is provided to the requesting agency and added to its ongoing investigative efforts. The investigative recommendations generated in stage 4 are applied, and suspects matching the profile are evaluated. If identification, apprehension, and a confession result, the goal of the profiling effort has been met. If new evidence is generated (e.g., by another murder) and/or there is no identification of a suspect, reevaluation occurs. The information is reexamined and the profile revalidated.

\subsubsection{Apprehension Stage}

Once a suspect is apprehended, the agreement between the outcome and the various stages in the profile-generating process are examined. When an apprehended suspect admits guilt, it is important to conduct a detailed interview to check the total profiling process for validity.

\subsection{Benefits of Criminal Profile}

A criminal investigation of any kind should start with the assumption that every human on the planet is a suspect. That is to say, the suspect set is universal. One of the purposes of criminal profiling is to assist an investigation, at any phase, in moving from that universal set of suspect characteristics to a more discrete set of suspect characteristics. It cannot typically point to a specific person or individuate one suspect from all others. It can, however, give insight into the general characteristics of the offender(s) responsible (Johnson, 2014). This type of insight can be used to educate an investigative effort, as well as 
attorneys, judges, and juries in a forensic context (e.g., criminal proceedings, civil proceedings, and public hearings).

Criminal profiling is mainly used when the offender does not leave any physical trace at the crime scene. As Douglas and Olshaker (1999) have pointed out, "criminal profiling is used mostly by behavioural scientists and the police to narrow down an investigation to those who possess certain behavioural and personality features that are revealed by the way a crime was committed. Continuing, Douglas and Olshaker also maintained that "the primary goal is to aid local police in limiting and refining their suspect list so that they can direct their resources where they might do the most good".

Another key use of a profile is when necessary, to go proactive, which means letting the public become partners in crime-solving. The unknown suspect may have displayed some sort of odd behaviour to those close to him that will indicate his involvement with the crime. Getting the public, and hopefully, those people to be aware of what they have seen, telling them to come forward may solve the case (Douglas and Olshaker, 1999). Egger (1999) maintained that "the purpose of profiling is to develop a behavioural composite, combining sociological and psychological assessments of the offender. Profiling is generally based on the premise that accurate analysis and interpretation of the crime scene and other locations related to the crime can indicate the type of person who committed the crime". Hence, "because certain personality types exhibit similar behavioural patterns (in other words, behaviour that becomes routine), knowledge and an understanding of the patterns can lead investigators to potential suspects" (Egger, 1999). Similarly, Jackson and Bekerian (1997) maintained that "a profile is based on the premise that the proper interpretation of crime scene evidence can indicate the personality type of the individual(s) who committed the offence. It is assumed that certain personality types exhibit similar behavioural patterns and that knowledge of these patterns can assist in the investigation of the crime and the assessment of potential suspects".

Holmes and Holmes (1996) have outlined three major goals of profiling as follows:

\subsubsection{Social and Psychological Assessments of Offenders}

This involves an evaluation of the social and psychological characteristics of the offender. In fact, "a profile should contain basic and sound information concerning the social and psychological core variables of the offender's personality, including the offender's race, age, employment status and type, religion, marital status, and level of education. This psychological information will help to focus the investigation by allowing police to narrow its range, which in turn will have a direct effect upon the number of days and weeks the police could spend on the case" (Holmes, and Holmes, 1996). It may also help the police to predict possible future attacks;

\subsubsection{Psychological Evaluations of Belongings Found in the Possession of Suspected Offenders}

This involves the evaluation of items found at the suspect's home, such as souvenirs taken from the crime scenes, pictures, videos, books, magazines, items of pornography, or other items that might point to the background and motives for the crimes, as well as link the suspect to the crime. Such physical evidence could be listed on a search warrant so the police take particular care to look for them. Holmes and Holmes noted the case of Jerry Brudos a sadistic serial killer in the United States who had such a fetish for his victims' high heeled shoes. He took their shoes, wore, and stored them at his home (David, 1994).

\subsubsection{Suggestions and Strategies for Interviewing Suspected Offenders when they are Apprehended}

Another primary goal of profiling is to suggest the most effective interviewing strategy to be used once the offender has been arrested. As there are different types of offenders, one interviewing/interrogation strategy may not be suitable for all the different types, especially when dealing with rapists. As Holmes and Homes have pointed out, "not all people react to questions in the same fashion. For one type of offender, one strategy may be effective, but it is a mistake to assume that all those who commit similar crimes will respond to the same interviewing strategy. For example, not all serial murderers kill for the same reasons, and not all respond to the same type of interviewing strategy. Violent personal offenders also vary in their motives as well as their responses to interrogation (David and Rupert, 1990). A good profile can provide the police with strategies that may be effective for a particular offender.

It has been observed that criminal profiling is usually taken up late in an investigation. It tends to be normally taken up as an alternative where DNA profiling is impossible because there were no samples 
left at the scene of the crime (Ebisike, 2001). There are certain dangers with this approach. It is therefore suggested that in serious/major crimes, criminal profiling should be used at the onset, along with the other techniques. It should not be left till later in the investigation when we have come to realize that no physical trace has been left at the crime scene, bearing in mind the issue of 'staged crime scenes'. Important details might be lost later in the investigation and as we know, crime scenes can be tampered with, by both weather conditions and human tampering (Johnson, 2014).

Brent E. Turvey (2011) divided criminal profiling into two separate but equal contexts, divided not by the method that is employed to arrive at conclusions, but rather by their divergent goals and priorities. Turvey (2011) continued that -these goals and priorities are dictated by a necessity that is dependent upon when, in a given case, a profiler's skills are requested. The twotime frames typically include the investigative phase, before a suspect has been arrested (or before a defendant is taken to court with a lawsuit), and the trial phase, while a suspect is being tried for a crime (or put on trial for damages).

\subsubsection{Investigative Phase}

The investigative phase involves behavioural evidence analysis of the patterns of unknown perpetrators of known crimes. Criminal profilers are invited in extremely violent, sexual, and/or predatory cases when witness testimony, confessions, and/or physical evidence have not been enough to move the investigation forward.

\subsubsection{Primary Goals}

a. Evaluating the nature and value of forensic and behavioural evidence in a particular crime or series of related crimes;

b. Reducing the viable suspect pool in a criminal investigation;

c. Prioritizing the investigation into remaining suspects;

d. Linkage of potentially related crimes by identifying crime scene indicators and behaviour patterns (i.e., modus operandi and signature);

e. Assessment of the potential for escalation of nuisance criminal behaviour to more serious or more violent crimes (i.e., harassment, stalking, voyeurism); f. Providing investigators with investigative relevant leads and strategies;

g. Helping keep the overall investigation on track and undistracted by offering fresh and unbiased insights;

h. Developing communication, interview, or interrogation strategies when dealing with suspects

\subsubsection{Trial Phase}

The trial phase of criminal profiling involves an analysis of known crimes for which there is a suspect or a defendant (sometimes a convicted defendant). It takes place in the preparation for hearings, trials, and post-conviction proceedings. Guilt, penalty, and appeal phases of the trial are all appropriate times to use profiling techniques, depending on the evidence at issue.

\subsubsection{Primary Goals}

a. Evaluating the nature and value of forensic and behavioural evidence to a particular crime or series of related crimes;

b. Helping to develop insight into offender fantasy and motivations; Developing insight into offender motive and intent before, during, and after the commission of a crime (i.e., levels of planning, evidence of remorse, precautionary acts, etc.);

c. Linkage of potentially related crimes by identifying crime scene indicators and behaviour patterns (i.e., modus operandi and signature).

\section{RECOMMENDATIONS}

Criminal profiling is of considerable importance to our criminal justice system in Nigeria since it has the potential of enriching the ability of the Nigeria Police Force to investigate, unravel and combat crimes more effectively. However, the following recommendations must be addressed for this to be possible and successful like those in other foreign jurisdiction:

1. The idea that certain kinds or degrees of crimes are uniquely western phenomena seems to pervade our minds as Nigerians, whether civilian or military. It is important therefore that awareness should be created and such myopic ideologies should be corrected and prevented especially among officers of the Nigeria Police Force. 
2. In Nigeria, many crimes are unreported. There is a direct relationship between the way the public perceives the police and the confidence the public has in the police. It is therefore safe to assume that if the relationship between the police and the members of the public is repaired and rendered relatively hostility-free, the citizenry would have more confidence in the police and report crimes more willingly.

3. Many times, reported crimes are not properly recorded and many records are not properly kept. The Nigeria police force should be upgraded such that the digital storage of information is undertaken. A database should be created such that it has up to date information on crimes as well as digitally stored criminal records which would greatly facilitate investigations as well as contribute immensely to the proper handling of crimes and criminals.

4. The police desperately need a holistic economic upgrade if any improvement is to be achieved. This must reflect in the recruitment, training, infrastructural facilities especially forensic training and facilities, equipment, maintenance, remuneration, and general welfare of the Nigeria Police Force and its members. The fact that this upgrade is capital intensive is well appreciated.

5. The training needs of the Nigeria Police Force should be determined. For example, the core functions of the police are crime prevention, crime control, law enforcement, prosecution, and assistance to citizens in distress. Crime control and prevention, and law enforcement require skills in surveillance, intelligence, and investigation. Therefore, there should be an emphasis on the training of officers in these core areas. Effective training in these areas requires adequate forensic and surveillance facilities (communication, transportation, electronic monitoring devices) in the country.

\section{CONCLUSION}

The relevance of criminal profiling as an investigative tool in the criminal justice system cannot be over-emphasized and the Nigerian criminal justice system cannot overlook the very essence of this field. Long overdue unsolved and mysterious cases that have gone cold may not have been so if criminal profiling had been used to determine the offenders behind them. Nigeria has had its fair share of unsolved criminal cases that have been dropped for lack of material evidence and this has been a major reason behind the poor public perception of the justice system.

After a critical examination of issues and several cases in this study, it is concluded that offender profiling is a very important tool in criminal investigations. It is also submitted that profiling of habitual, serial, and violent offenders would enhance the effectiveness of criminal investigations in Nigeria. With the contents of this paper, It is hoped that the effectiveness of this field has been highlighted and that the use of criminal investigative analysis will be effectively immersed into the Nigerian criminal justice system and receive as much recognition as it has in other jurisdictions especially in the United States of America, United Kingdom and in major parts of Europe.

\section{REFERENCES}

Adeyemi, D. (2011) The Import Of Criminal Profiling In The Investigation of Violent Crimes In Nigeria, Faculty Of Law, University Of Ibadan.

Alemika, E. E. O. (1993) "Colonialism, State and Policing in Nigeria” Crime, Law and Social Change 20: $187-219$. https://doi.org/10.1007/BF01308450

Alison, L. (Ed.) (2005). The Forensic Psychologist's Casebook: Psychological Profiling and Criminal Investigation. Willan: UK.

Anthony, P. and Norman, F. (1990) Criminal Profiling, Law and Human behaviour.14(3) (Official Journal of the American Psychology of Law Society)

Arrigo, B.A. \& Shipley, S.L. (2005). Introduction to Forensic Psychology (2nd ed.). New York: Elsevier Academic Press. https://doi.org/10.1016/B978-012064351-6/50003-X

Ashley burns, (2009) UNL forensic science professors present workshops in Nigeria, published Monday, October 12, 2009; http://www.dailynebraskan.com/news/unl-forensic-scienceprofessors-present-workshops-in-nigeria-1.994406

Bartol, C.R. and Bartol, A.M. (1994) Psychology and law. Pacific Grove, CA: Brooks/Cole.

Brewer, N. \& Williams, K.D. (Ed.). (2005). Psychology and Law: An Empirical Perspective. New York: Guilford Press.

Brown, J., Shell, Y., \& Cole, T. (2015). Forensic psychology: Theory, research, policy and practice. Sage Publications. https://doi.org/10.4135/9781473922228

Canter, D. \& Heritage, R. (1989). A multivariate model of sexual offence behaviour: developments in offender profiling. $J$ Forensic Psychiatry, 1, 185-212. https://doi.org/10.1080/09585189008408469

Canter, D. (1989). Offender profiles. Psychologist, 2(1), 12-16.

Canter, D. (1994). Criminal Shadows. London: Harper Collins.

Canter, D. and Rupert H., (1990) "A Multivariate Model of Sexual Offence Behaviour: Developments In Offender Profiling", Journal of Forensic Psychiatry. https://doi.org/10.1080/09585189008408469

Canter, D.V. \& Fritzon, K. (1998). Differentiating arsonists: a model of firesetting actions and characteristics. Legal and Criminological Psychology, 5, 23-46. https://doi.org/10.1348/135532500167958 
Central Intelligence Agency (2011) The World Factbook: http://www.cia.gov/library/publications/the-worldfactbook/geos/ni.html Accessed July 4, 2019.

Chu, C., Daffern, M., Thomas, S., Ang, Y., \& Long, M. (2014). Criminal attitudes and psychopathic personality attributes of youth gang offenders in Singapore. Psychology, Crime \& Law, 20(3), 284-301. https://doi.org/10.1080/1068316X.2013.772182

Clare, P. K and Kramer, J. H. (1977) Introduction to American Corrections, Boston, MA: Holbrook Press, Inc.

Douglas, J. (1986) Criminal Profiling From Crime Scene Analysis; Behavioural Sciences and The Law 403. 4(4) https://doi.org/10.1002/bsl.2370040405

Douglas, J. E. (1981) Evaluation of the FBI Psychological Profiling Programme; Quantico, VA; FBI Academy, Institutional Research \& Development Unit.

Douglas, J. J., and Olshaker, M. (1999) Mindhunter: Inside the FBI's Elite Serial Crime Unit, New York Pocket Books.

Ebisike N. (2001) An Appraisal of the Forensic Science Evidence In Criminal Proceeding" London Greenway Press.

Egger, S. (2003) The need to kill: Inside the world of the serial killer. Upper Saddle River, NJ: Prentice-Hall. https://doi.org/10.1177/1043986299015003003

Egger, S. A. (1999) Psychological Profiling: Past, Present, and Future, Journal of Contemporary Criminal Justice,15(3) August 1999,243.

Ezeanya, A. U. (2015) Criminal Profiling and its Relevance in the Nigerian Criminal Justice System. A Long Essay Submitted to the Faculty of Law in partial fulfillment of the requirements for the Award of the Bachelor of Laws (LL.B) Degree of the University of Ibadan, Ibadan, Nigeria.

Geberth, V.J. (1983) Practical homicide investigation: Tactics, procedures and forensic techniques. Boca Raton, FL: CRC Press.

Hickey, E. (2003) The encyclopaedia of murder and violent crime. Thousand Oaks, CA:Sage. https://doi.org/10.4135/9781412950619

Holmes, R. M. and Holmes, S. T. (1996) Profiling Violent Crimes: An Investigative Tool, $\left(2^{\text {nd }}\right.$ ed. $)$ Thousand Oaks, Sage Publications.
Iwerimie-Jaja, D. (2003) Criminology: The Study of Crime, Owerri, Springfield Publishers Ltd.

Jackson, J. L. and Bekerian D. A. (eds), (1997) Criminal profiling: Theory, Research and Practice, 3, Chichester, John Wiley.

Johnson, S. (2014) How do offenders choose to offend? Perspectives from animal foraging, in Legal and Criminological Psychology, 19(2), pp.193-201 https://doi.org/10.1111/lcrp.12061

Onimajesin S. I. (2010) Criminal Justice System in Nigeria: An Appraisal, Department Of Sociology, University Of Ilorin, Nigeria.

O'Toole, M., (1999) "Criminal Profiling: The FBI Use Criminal Investigative Analysis to Solve Crimes"; Corrections

Palermo, B. G., (2002) "Criminal Profiling: The Uniqueness of the Killer"; International Journal of Offender Therapy https://doi.org/10.1177/0306624X02464001

Palermo, B. G., and Kocsis, N. R., (2005) Offender Profiling: An Introduction to the Sociopsychological Analysis of Violent Crime; Springfield, Charles C. Thomas Publishers. p. 183.

Petherick, W. (2003)."What's in a Name? Comparing Applied Profiling Methodologies" Journal of Law and

Salfati, C.G. (2000). The nature of expressiveness and instrumentality in homicide. Homicide Studies, 4(3), 265293. https://doi.org/10.1177/1088767900004003004

Turvey, B.(2002) Criminal Profiling: An Introduction to Behavioral Evidence Analysis; San Diego, Academic Press, (2nd ed).

Turvey, B., (2011) Criminal Profiling, 4th Ed., London: Elsevier Science http://forensicvictimology.blogspot.com/2013/07/ Criminal-Profiling-Behavioral-Evidence-Analysis.html

Tyler, T.R. and Wakslak, C.J. (2004). Profiling and police legitimacy: Procedural justice attributions of motive, and acceptance of police authority. Criminology, 42(2), 253-281. https://doi.org/10.1111/j.1745-9125.2004.tb00520.x

Uduma Kalu, (2009) Why Police Can"t Solve High Profile Murders, Say CP Onashile, Arthur-Worrey, Vanguard Nigeria.

\section{INTERNET}

http://www.dailynebraska.com

Received on 19-09-2020

Accepted on 11-01-2021

Published on 01-02-2021

DOI: https://doi.org/10.6000/1929-4409.2021.10.25

(C) 2021 Adebisi and Olanrewaju; Licensee Lifescience Global.

This is an open access article licensed under the terms of the Creative Commons Attribution Non-Commercial License (http://creativecommons.org/licenses/by-nc/3.0/) which permits unrestricted, non-commercial use, distribution and reproduction in any medium, provided the work is properly cited. 